... Wentzel, González-Prieto, Brischke, Militz: Physico-Mechanical Properties of Thermally...

Maximilian Wentzel' ${ }^{1}$, Óscar González-Prieto², Christian Brischke ${ }^{1}$, Holger Militzl

\title{
Physico-Mechanical Properties of Thermally Modified Eucalyptus Nitens Wood for Decking Applications
}

\section{Fizička i mehanička svojstva toplinski modificiranog drva Eucalyptus nitens za vanjske podne obloge}

\author{
Original scientific paper • Izvorni znanstveni rad \\ Received-prispjelo: 30. 8. 2018. \\ Accepted-prihvaćeno: 4. 7. 2019. \\ UDK: $630 * 812.22 ; 630 * 812.73 ; 630 * 812.791$ \\ https://doi.org/10.5552/drvind.2019.1838
}

\begin{abstract}
Eucalyptus nitens is a fast growing plantation species that has a good acclimation in Spain and Chile. At the moment it is mainly used for pulp and paper production, but there is a growing market for solid wood products made from this species. Thermal modification offers a good alternative to produce high quality material to manufacture products with high added value. This study used unmodified and thermally modified E. nitens wood from Spanish and Chilean plantations to elaborate external decking and examine if it complies with the necessary properties to be a competitive product. A process similar to ThermoWood ${ }^{\circledR}$ was applied at the following temperatures: $185^{\circ} \mathrm{C}, 200{ }^{\circ} \mathrm{C}$ and $215^{\circ} \mathrm{C}$. For each modification and for an unmodified specimen mass loss, volumetric swelling, anti-swelling efficiency (ASE) and equilibrium moisture content (EMC) were determined. Brinell hardness, dynamic hardness, screw and nail withdrawal resistance, and abrasion resistance according to the Shaker method and the Taber Abraser method were also determined. According to this study, thermally modified E. nitens from both countries showed high potential to be used as decking material, particularly when modified at $200{ }^{\circ} \mathrm{C}$.
\end{abstract}

Keywords: Eucalypt, anti-swelling efficiency (ASE), hardness, abrasion resistance, timber

SAŽETAK • Eukaliptus nitens brzo je rastuća plantažna vrsta koja se dobro prilagodila klimi u Španjolskoj $i$ Čileu. Trenutačno se uglavnom iskorištava za proizvodnju celuloze i papira, ali sve je veće tržište proizvoda izrađenih od masivnog drva te vrste. Toplinskom modifikacijom dobiva sa dobra alternativa za proizvodnju visokokvalitetnih proizvoda s visokom dodanom vrijednošću. U ovom je istraživanju kao materijal za vanjske podne obloge upotrijebljeno nemodificirano i toplinski modificirano drvo E. nitens sa španjolskih i čileanskih plantaža te je ispitana njegova sukladnost sa svojstvima potrebnima za postizanje konkurentnosti. Primijenjen je postupak sličan procesu ThermoWood ${ }^{\circledR}$, i to pri temperaturama 185, 200 i $215^{\circ} \mathrm{C}$. Za svaki modificirani i nemodificirani uzorak određen je gubitak mase, volumno bubrenje, učinak smanjenja bubrenja (ASE) i ravnotežni sadržaj vode (EMC). Određene su i tvrdoća prema Brinellu, dinamička tvrdoća, otpornost na izvlačenje vijaka i čavala te otpornost na

\footnotetext{
${ }^{1}$ Authors are researchers and professor at University of Goettingen, Department of Wood Biology and Wood Products, Goettingen, Germany. ${ }^{2}$ Author is associate professor at University of Vigo, Department of Natural Resources and Environment Engineering, Pontevedra, Spain. Autori su istraživači i profesor Sveučilišta u Goettingenu, Zavod za biologiju i proizvode od drva, Goettingen, Njemačka. ${ }^{2}$ Autor je izvanredni profesor Sveučilišta u Vigu, Zavod za prirodne resurse i inženjerstvo okoliša, Pontevedra, Španjolska.
} 
habanje prema metodama Shaker $i$ Taber abraser. Na temelju ovog istraživanja može se zaključiti da su toplinski modificirani uzorci drva E. nitens iz obje zemlje pokazali visok potencijal za uporabu u obliku vanjskih podnih obloga, posebice ako su modificirani pri $200^{\circ} \mathrm{C}$.

Ključne riječi: eukalipt, učinak smanjenja bubrenja (ASE), tvrdoća, otpornost na habanje, drvo

\section{INTRODUCTION}

\section{UVOD}

In the last 30 years there has been a steady growth of Eucalyptus nitens plantations in south of Chile and in the region of Galicia in Spain, as it is a species with great adaptability to frost and colder climate conditions. In Chile, there are about 250,000 ha planted as of 2014 (INFOR, 2015), while in Spain no official data are available. Only the current review for the Forestry Plan of Galicia (Xunta de Galicia, 2018), which analyzed the Spanish Forestry Inventory, and the Spanish Forestry Map suggested for E. nitens in this region forests of approximately 40,000 ha, and proposed an increase of 30.000 ha during the next 20 years. However, this number should be higher, as E. nitens plantations have been replacing E. globulus plantations due to its higher resistance against pathogens and cold.

Currently, E. nitens plantation wood is mostly used for pulp and paper or biofuels, but there is an interest to widen the use of this fast growing tree species. Solid wood made out of plantation E. nitens is being sold at the moment in Chile, but it cannot compete with other fast growing species, as the volume of plantations of radiata pine in Chile (INFOR, 2015) allows the species to maintain a competitive low price. As for Spain, there is still no market for dry E. nitens solid wood, but similar species (E. globulus). Thermal modification offers a good alternative to produce high quality material from this species that could be used for decking, claddings, windows, doors, flooring, garden products and even saunas or bathrooms (Militz and Altgen, 2014). Most thermal modification processes apply temperatures between $160{ }^{\circ} \mathrm{C}$ and $240{ }^{\circ} \mathrm{C}$ and limit the oxygen content during the process (Hill, 2006; Esteves and Pereira, 2009; Militz and Altgen, 2014). E. nitens (durability class 4, Australian Standard 5604 2005) and other eucalypt species, such as E. globulus, E. grandis, E. regnans and E. pellita (durability in ground contact class 3 - 4, Australian Standard 5604 2005), have been used as material for thermal modification (Esteves et al., 2007a; Esteves et al., 2007b; González-Prieto and Touza Vázquez, 2009; Calonego et al., 2012; Wang et al., 2014; de Cademartori et al., 2015; Wentzel et al. 2019). In most cases research has been focused on the variation of color, the changes of the mechanical and physical properties and variations of the chemical composition.

In Eucalypt species, durability increases after thermal modification, as it has been shown in the resistance against the brown rot fungus Gloeophyllum trabeum for modified E. globulus from durability class 3 (DC 3, moderately durable) to DC 1 (very durable) (González-Prieto and Touza Vázquez, 2009). Changes in mechanical properties of thermally modified Eucalypt species, such as a slight increase of $M O E$ and a decrease in MOR (Table 1), were not a detriment of the potential for using this species for outdoor materials (Esteves et al., 2007a; Calonego et al., 2012; de Cademartori et al., 2015; Knapic et al., 2018; Wentzel et al., 2019), as the MOE and MOR were still higher than those of commonly used WPC boards (Dias and Alvarez, 2017), a material commonly used for decking production (Zeller, 2018).

Currently, tropical woods such as Bangkirai (Shorea laevis), IPE-Lapacho (Tabulea spp.) or European-grown timbers such as Douglas fir (Pseudotsuga menziesii) and Larch (Larix spp.), and preservative treated pine are the most commonly used materials for decking. In addition to these traditional decking materials in Europe, wood polymer composite (WPC) decking is gaining market share throughout Europe (Zeller, 2018) not at least due to their good capabilities to suppress the moisture uptake and resulting moisture movements, but also due to the thermal conductivity of polymers. Thermal modification improves natural durability and dimensional stability, and decreases the equilibrium moisture content (EMC) of wood (Stamm and Hansen, 1937; Hill, 2006; Esteves and Pereira, 2009). Živković et al. (2008) used thermally modified ash (Fraxinus spp.) and beech (Fagus sylvatica) as flooring elements. When compared to unmodified wood, it showed a lower EMC in room conditions and an improvement in dimensional stability.

Thermal modification also leads to an embrittlement of wood coming along with reduced abrasion resistance and the risk of splintering on the wood surface (Kubojima et al., 2000; Phuong et al., 2007). Surface hardness and resistance to abrasion are critical properties in less and non-load-bearing applications. In the case of decking, surface hardness turns into a decisive property for its use (Brischke et al., 2005). Welzbacher et al. (2009) showed that thermally treated beech and larch heartwood (Larix decidua) presented less abrasion and crack formation in relation to the unmodified wood, but showed long term discoloration by weathering. It is also important to consider how to connect the wood when installing the material. For outside use of thermally modified wood, it is recommended to use stainless screws and embedding screw heads (Aytin et al., 2015).

In this study the abrasion resistance, hardness (Brinell and dynamic), screw withdrawal resistance $(S W R)$, maximum swelling, anti-swelling efficiency $(A S E)$ and equilibrium moisture content (EMC) of thermally modified Eucalypt were determined since they are critical characteristics of outdoor exposed decking. 
... Wentzel, González-Prieto, Brischke, Militz: Physico-Mechanical Properties of Thermally...

Table 1 Highest and lowest $M O E$ and $M O R$ from various thermally treated Eucalypts under different process conditions and their respective control values of unmodified specimens

Tablica 1. Najveći i najmanji modul elastičnosti i modul loma različitih toplinski obrađenih eukalipta pri različitim uvjetima obrade i vrijednosti njihovih nemodificiranih uzoraka

\begin{tabular}{|c|c|c|c|c|c|c|c|c|c|c|}
\hline \multirow[t]{2}{*}{$\begin{array}{c}\text { Species } \\
\text { Vrsta }\end{array}$} & \multirow{2}{*}{$\begin{array}{c}\text { Thermal } \\
\text { modification } \\
\text { Toplinska } \\
\text { modifikacija }\end{array}$} & \multicolumn{2}{|c|}{$\begin{array}{c}\text { Tempera- } \\
\text { ture, }{ }^{\circ} \mathbf{C} \\
\text { Temperatura, } \\
{ }^{\circ} \mathrm{C} \\
\end{array}$} & \multirow{2}{*}{$\begin{array}{l}\text { MOE Unmodi- } \\
\text { fied specimen, } \\
\text { MPa } \\
\text { MOE nemodi- } \\
\text { ficiranih } \\
\text { uzoraka, MPa }\end{array}$} & \multirow{2}{*}{$\begin{array}{l}\text { MOR Unmodi- } \\
\text { fied specimen, } \\
\text { MPa } \\
\text { MOR nemodi- } \\
\text { ficiranih } \\
\text { uzoraka, } \mathrm{MPa} \\
\end{array}$} & \multicolumn{2}{|c|}{$\begin{array}{c}\text { MOE } \\
\mathrm{MPa}\end{array}$} & \multicolumn{2}{|c|}{$\begin{array}{c}\text { MOR, } \\
\mathrm{MPa}\end{array}$} & \multirow[t]{2}{*}{$\begin{array}{c}\text { Refer- } \\
\text { ence } \\
\text { Literatura }\end{array}$} \\
\hline & & $\min$ & $\max$ & & & $\min$ & $\max$ & $\min$ & $\max$ & \\
\hline E. nitens & \begin{tabular}{|c|} 
Laboratory scale \\
reactor (atmospheric \\
pressure) \\
laboratorijski \\
reaktor (atmosfer- \\
ski tlak) \\
\end{tabular} & 160 & 230 & 18449 & 119 & 14604 & 22224 & 88 & 134 & $\begin{array}{l}\text { Wentzel } \\
\text { et al., } \\
2019\end{array}$ \\
\hline E. nitens & $\begin{array}{l}\text { Laboratory scale } \\
\text { reactor (high } \\
\text { pressure) } \\
\text { laboratorijski } \\
\text { reaktor (visoki tlak) }\end{array}$ & 150 & 170 & 18449 & 119 & 14464 & 16131 & 85 & 117 & $\begin{array}{l}\text { Wentzel } \\
\text { et al., } \\
2019\end{array}$ \\
\hline $\begin{array}{c}E . \\
\text { grandis }\end{array}$ & $\begin{array}{c}\text { Modified autoclave } \\
\text { (air atmosphere) } \\
\text { modificirani } \\
\text { autoklav (zračna } \\
\text { atmosfera) } \\
\end{array}$ & 180 & 240 & 12097 & 89 & 10623 & 12091 & 69 & 41 & $\begin{array}{l}\text { de } \\
\text { Cademar- } \\
\text { tori et al., } \\
2015\end{array}$ \\
\hline $\begin{array}{c}E . \\
\text { saligna }\end{array}$ & $\begin{array}{c}\text { Modified autoclave } \\
\text { (air atmosphere) } \\
\text { modificirani } \\
\text { autoklav (zračna } \\
\text { atmosfera) } \\
\end{array}$ & 180 & 240 & 12869 & 90 & 12568 & 12805 & 75 & 47 & $\begin{array}{l}\text { de } \\
\text { Cademar- } \\
\text { tori et al., } \\
2015\end{array}$ \\
\hline $\begin{array}{c}E . \\
\text { grandis }\end{array}$ & $\begin{array}{c}\text { Modified laboratory } \\
\text { oven / modificirani } \\
\text { laboratorijski } \\
\text { sušionik }\end{array}$ & 140 & 220 & 12800 & 69 & 12100 & 12400 & 65 & 33 & $\begin{array}{l}\text { Calonego } \\
\text { et al., } \\
2012\end{array}$ \\
\hline $\begin{array}{c}E . \\
\text { globulus }\end{array}$ & $\begin{array}{c}\text { Modified laboratory } \\
\text { oven / modificirani } \\
\text { laboratorijski } \\
\text { sušionik }\end{array}$ & 170 & 200 & 14197 & - & 10647 & 14339 & - & - & $\begin{array}{l}\text { Esteves et } \\
\text { al., 2007a }\end{array}$ \\
\hline $\begin{array}{c}E . \\
\text { globulus }\end{array}$ & $\begin{array}{c}\text { Modified laboratory } \\
\text { oven / modificirani } \\
\text { laboratorijski } \\
\text { sušionik }\end{array}$ & - & 210 & 13909 & 111 & - & 13379 & - & 102 & $\begin{array}{c}\text { Knapic et } \\
\text { al., } 2018\end{array}$ \\
\hline
\end{tabular}

\section{MATERIALS AND METHODS} 2. MATERIJALI I METODE

\subsection{Material \\ 2.1. Materijal}

The Chilean E. nitens wood came from 19 year old plantations from the Región del Bío-Bío in Chile, while the wood from Spain came from 16 year old plantations from the north of the province of Lugo in Galicia. The wood specimens were taken randomly from piles of industrially dried wood from general production lines from sawmills in Chile and Spain, which is why the humidity was different at the same laboratory conditions before modification and there was a difference in their respective thickness. Flat sawn slats of $20 \mathrm{~mm} \times 60 \mathrm{~mm} \times 650 \mathrm{~mm}$ and $30 \mathrm{~mm} \times 50 \mathrm{~mm} \times$ $650 \mathrm{~mm}$ (radial $\times$ tangential $\times$ longitudinal) size, for the Chilean and Spanish origin, respectively, were prepared from kiln-dried wood free of large knots. Before the modification process, the slats from Chile had an average moisture content of $13 \%$, whereas the ones from Spain had an average of $15 \%$. Twelve slats (six for each country of origin) per modification process were used.

\subsection{Thermal modification \\ 2.2. Toplinska modifikacija}

Thermal modification was performed in a laboratory-scale treatment reactor. The modification followed the ThermoWood ${ }^{\circledR}$ process (Mayes and Oksanen, 2002) and contained the following steps: The temperature in the vessel was first raised at $12{ }^{\circ} \mathrm{C} / \mathrm{h}$ to $100^{\circ} \mathrm{C}$ and then at $2^{\circ} \mathrm{C} / \mathrm{h}$ to $130{ }^{\circ} \mathrm{C}$ to allow a high-temperature drying of the slats to nearly $0 \% \mathrm{MC}$, before increasing the temperature again at $12{ }^{\circ} \mathrm{C} / \mathrm{h}$ until reaching the peak temperatures $\left(185,200\right.$ and $\left.215^{\circ} \mathrm{C}\right)$. The peak temperature was hold for $3 \mathrm{~h}$. Afterwards, the temperature was decreased at $20^{\circ} \mathrm{C} / \mathrm{h}$ until reaching $65^{\circ} \mathrm{C}$, at which the vessel was opened and the specimens were removed. 


\subsection{Determination of mass loss $(M L)$}

\subsection{Određivanje gubitka mase $(M L)$}

To determine the mass loss $(M L)$ for each modified slat caused by the thermal modification, an adaptation of the procedure reported by Metsä-Kortelainen et al. (2006) was applied. The mass and the corresponding wood moisture content $(M C)$ were recorded for each slat before and immediately after the process.

\subsection{Determination of oven-dry density}

2.4. Određivanje gustoće apsolutno suhog drva

The oven-dry density was determined according to ISO 13061-2 (2014) using five $8.5 \mathrm{~mm} \times 8.5 \mathrm{~mm} \times$ $35 \mathrm{~mm}$ (rad. $\times$ tang. $\times$ long.) specimens per modification, which were oven dried at $(103 \pm 2){ }^{\circ} \mathrm{C}$ until constant mass. They were then weighed to the closest $0.01 \mathrm{~g}$ and their dimensions were measured to the nearest $0.01 \mathrm{~mm}$.

2.5 Determination of equilibrium moisture content $(E M C)$, volumetric swelling $\left(S_{\max }\right)$ and antiswelling efficiency ( $A S E)$

2.5. Određivanje ravnotežnog sadržaja vode $(E M C)$, volumnog bubrenja $\left(S_{\text {max }}\right)$ i učinka smanjenja bubrenja $(A S E)$

To measure $E M C, S_{\max }$ and $A S E, 30$ specimens per process run with dimensions of $10 \mathrm{~mm} \times 10 \mathrm{~mm} \times$ $10 \mathrm{~mm}$ (rad. $\times$ tang. $\times$ long.) were prepared from the modified wood and from unmodified references. The mass and the dimensions of the specimens were measured after each of the following steps: Conditioning at $20{ }^{\circ} \mathrm{C} / 65 \% \mathrm{RH}$ until constant weight; oven drying at $103{ }^{\circ} \mathrm{C}$ until constant mass; water saturating (specimens were water-impregnated for $30 \mathrm{~min}$ at $13 \mathrm{kPa}$ and water soaked for 14 days).

The $E M C$ (in \%) at $20{ }^{\circ} \mathrm{C}$ and $65 \% \mathrm{RH}$ was determined for each sample using Eq. 1:

$$
E M C=100 \cdot\left(m_{\mathrm{A}}-m_{\mathrm{B}}\right) / m_{\mathrm{B}},
$$

where $m_{\mathrm{A}}$ and $m_{\mathrm{B}}$ is the mass (in $\mathrm{g}$ ) at the end of step A and $\mathrm{B}$, respectively.

$S_{\max }$ (in \%) was measured based on the sample volume at the end of step $B$ and $C$ for each cycle using Eq. 2:

$$
S_{\max }=100 \cdot\left[\left(V_{\mathrm{C}}-V_{\mathrm{B}}\right) / V_{\mathrm{B}}\right],
$$

where $V_{\mathrm{B}}$ and $V_{\mathrm{c}}$ are the sample volumes at the end of step $\mathrm{B}$ and $\mathrm{C}$, respectively.

$A S E$ (in \%) was measured using the $S_{\max }$ before and after modification using Eq. 3:

$$
A S E=S u_{\max }-S m_{\max } / S u_{\max } \cdot 100
$$

where $S u_{\max }$ is the maximum swelling of the unmodified sample and $S m_{\max }$ is the maximum swelling of the modified sample, respectively.

\subsection{Brinell hardness tests}

\subsection{Tvrdoća prema Brinellu}

The Brinell hardness (static hardness) was measured according to DIN EN 1534 (2011) with a universal testing machine (Zwick Roell Z010, Zwick, Ulm, Germany). Ten specimens per modification and country of origin were used. A maximum force of $500 \mathrm{~N}$ using a steel ball with a diameter of $10 \mathrm{~mm}$ was applied for 25 seconds on specimens of $15 \mathrm{~mm} \times 50 \mathrm{~mm} \times 50$ mm (rad. $\times$ tang. $\times$ long.) for the Chilean wood, and $25 \mathrm{~mm} \times 50 \mathrm{~mm} \times 50 \mathrm{~mm}$ (rad. $\times$ tang. $\times$ long.) for the Spanish wood. The specimens were conditioned at $20{ }^{\circ} \mathrm{C} / 65 \% \mathrm{RH}$ during seven days until constant weight. The diameter of the residual impression was automatically determined by the testing machine. The Brinell hardness was then calculated according to Eg. 4:

$$
B H=2 \cdot F / \pi \cdot D\left[D-\sqrt{\left(D^{2}-d^{2}\right)}\right],
$$

where $B H$ is the Brinell hardness $\left(\mathrm{N} / \mathrm{mm}^{2}\right), F$ is the maximum force used $(\mathrm{N}), D$ is the diameter of the steel ball (mm) and $d$ is the diameter of the imprint on the sample (mm).

\subsection{Dynamic hardness tests \\ 2.7. Dinamička čvrstoća}

The dynamic hardness was determined according to Meyer et al. (2011) using specimens of the same quantity and dimensions as for the Brinell hardness tests. An indentation was generated in the surface of the specimen using a steel weight of $500 \mathrm{~g}$ that was dropped down on a steel ball from $300 \mathrm{~mm}$ of height. Four measurements were conducted on five replicates per material. The dynamic hardness was calculated according to Eq. 5:

$$
D H=m \cdot \sqrt{(2 \cdot g \cdot h)} / r^{2} \cdot \pi
$$

where $D H$ is the dynamic hardness $\left(\mathrm{N} / \mathrm{mm}^{2}\right), m$ is the mass of the dropping weight $(\mathrm{kg}), h$ is the dropping height $(\mathrm{m}), r$ is the radius of the imprint on the sample $(\mathrm{mm})$ and $g$ is the gravity acceleration $\left(\mathrm{m} / \mathrm{s}^{2}\right)$.

\subsection{Resistance to abrasion: Shaker test \\ 2.8. Otpornost na habanje: metoda Shaker}

The resistance against abrasion was determined using the Shaker method described by Brischke et al. (2005). Five oven-dry specimens of $8.5 \mathrm{~mm} \times 8.5 \mathrm{~mm}$ $\times 35 \mathrm{~mm}$ (rad. $\times$ tang. $\times$ long. $)$ were placed in polyethylene flasks $(V=500 \mathrm{~mL})$ together with $400 \mathrm{~g}$ stainless steel balls of $6 \mathrm{~mm}$ in diameter and shaken in an overhead shaker at 28 revolutions per minute during $72 \mathrm{~h}$. 25 specimens per material were tested. The distances between the opposite corners at oven-dry state were measured of each specimen, before and after the abrasion process. The loss in dimension (\%) was determined according to Eq. 6:

$\Delta a b=\left[\left(d_{\mathrm{a} 1}+d_{\mathrm{a} 2} / 2\right)-\left(d_{\mathrm{b} 1}+d_{\mathrm{b} 2} / 2\right) /\left(d_{\mathrm{b} 1}+d_{\mathrm{b} 2} / 2\right)\right] \cdot 100$

where $\Delta a b$ is the abrasion (\%), $d_{\mathrm{b} 1}$ is the diagonal 1 before abrasion ( $\mathrm{mm}), d_{\mathrm{b} 2}$ is the diagonal 2 before abrasion $(\mathrm{mm}), d_{\mathrm{a} 1}$ is the diagonal 1 after abrasion $(\mathrm{mm})$ and $d_{\mathrm{a} 2}$ is the diagonal 2 after abrasion ( $\mathrm{mm}$ ). The average of the 5 samples per flax bottle was determined for each modification.

\subsection{Resistance to abrasion: Taber Abraser test} 2.9. Otpornost na habanje: metoda Taber abraser

The resistance against abrasion was determined according to the Taber Abraser method (EN 438-2, 2005). The following modifications of the Taber Abra- 
ser test were made in order to allow testing of solid wood: Specimens $(\mathrm{n}=4)$ of $100 \mathrm{~mm} \times 100 \mathrm{~mm} \times 7 \mathrm{~mm}$ of a finished decking were prepared and conditioned in $20{ }^{\circ} \mathrm{C} / 65 \% \mathrm{RH}$. The tree rings of all specimens had an orientation of $45^{\circ}$ to their cutting edges. After weighing and measuring the thickness at four points over the ridges of the decking, the specimens $(n=5)$ were clamped into the Taber Abraser and were abraded with sanding paper S-42 with approx. $72 \mathrm{~min}^{-1}$ for 1000 revolutions. Each wheel had a load of $500 \mathrm{~g}$. Afterwards the decrease in thickness at each of the four abrasion points was determined. The percentage loss in thickness $(\Delta \mathrm{t})$ was determined as a measure of abrasion according to the following Eq. 7 for each specimen and an average was calculated:

$$
\Delta t=\left(t_{\mathrm{b}}-t_{\mathrm{a}} / t_{\mathrm{b}}\right) \cdot 100
$$

where $t_{\mathrm{b}}$ is the thickness ( $\mathrm{mm}$ ) before the Taber Abrasion test and $t_{\mathrm{a}}$ is the thickness (mm) after the test.

\subsection{Screw withdrawal resistance tests}

2.10. Ispitivanje otpornosti na izvlačenje vijaka

Screw withdrawal resistance $(S W R)$ tests were performed according to EN 320 (2011), but modified as follows: The same quantity and size of specimens used for the Brinell hardness test were used. Screws with nominal dimensions of $4.2 \mathrm{~mm} \times 38 \mathrm{~mm}$ were used to penetrate the tangential face until $(15 \pm 0.5) \mathrm{mm}$. Afterwards the screws were attached to a bracket to be pulled out at a constant speed of $(10 \pm 1) \mathrm{mm} \mathrm{min}^{-1}$. The screw withdrawal resistance corresponds to the maximum force determined to $10 \mathrm{~N}$ and was measured according to equation 8 :

$$
S W R=N_{\max } / t
$$

where $S W R$ is the screw withdrawal resistance, $N_{\max }$ the maximum force $(\mathrm{N})$ and $t$ the thickness of the specimen (mm).

\subsection{Statistical evaluation}

2.11. Statistička analiza

Statistical analysis was performed using the Pearson Correlation Coefficient Test to show the correlations between the mass loss and density with the properties of the modified wood, and an ANOVA test to see if there was a significant difference between the unmodified and the modified wood properties. All statistics were performed using the Statistica Software package Version 13.1 (StatSoft Inc., Tulsa, USA).

\section{RESULTS AND DISCUSSION 3. REZULTATI I RASPRAVA}

3.1 Changes in mass, oven dry density, EMC, swelling and $A S E$ by thermal modification

3.1. Promjene mase, gustoće apsolutno suhog drva, EMC-a, bubrenja i $A S E-$-a zbog toplinske modifikacije

$M L$ increased with rising treatment temperature (Table 2), which is in line with increasing $M L$ obtained in tests with other Eucalypt species at similar process conditions, such as E. saligna (from $12.77 \%$ at $180{ }^{\circ} \mathrm{C}$ and $19.12 \%$ at $220{ }^{\circ} \mathrm{C}$ ) in a modified autoclave modification (de Cademartori et al., 2015) and E. globulus $\left(8.7 \%\right.$ at $190{ }^{\circ} \mathrm{C}$ and $12.1 \%$ at $\left.200{ }^{\circ} \mathrm{C}\right)$ in a modified laboratory oven modification (Esteves et al., 2007a). The higher $M L$ of those modifications could be related to the different species and equipment used to do the modifications. Specimens from Chile and Spain showed similar $M L$ at each modification temperature. On the other hand, oven-dry density (Table 1) decreased with increasing modification temperature, which also occurred in vacuum-thermally modified $E$. pellita wood (Wang et al., 2014) and E. grandis (Calonego et al., 2012). The oven-dry density of the Spanish wood specimens was lower than that of the Chilean ones.

The $E M C$ of the modified wood was reduced in both the Chilean and Spanish specimens (Figure 1a) after all the thermal modifications, and so was $S_{\max }$ (Figure 1b). Eucalypt modified under similar conditions, such as E. grandis in both EMC $\left(5.9 \%\right.$ at $200{ }^{\circ} \mathrm{C}$ and $4.6 \%$ at $\left.220^{\circ} \mathrm{C}\right)$ and $S_{\max }\left(9.94 \%\right.$ at $200{ }^{\circ} \mathrm{C}$ and 6.6 $\%$ at $220^{\circ} \mathrm{C}$ ) (Calonego et al., 2012) and EMC (3.1\% at $190{ }^{\circ} \mathrm{C}$ and $2.8 \%$ at $210^{\circ} \mathrm{C}$ ) in E. globulus (Esteves et al., 2007b), showed similar results. Compared with other tropical wood species used for decking (Choong and Achmadi, 2007), the EMC of E. nitens was lower after treatment at $215^{\circ} \mathrm{C}$ and similar at $185{ }^{\circ} \mathrm{C}$ and $200^{\circ} \mathrm{C}$. ASE of E. nitens was lower after modification at $185{ }^{\circ} \mathrm{C}(26.14 \%$ and $23.11 \%$ for Chile and Spain, respectively) (Figure 1c) compared to the modifications at higher temperatures. This improvement of the

Table 2 Mean mass loss (ML) determined for each process run and oven-dry density for each modification and unmodified reference (standard deviation in parentheses) for both Chilean and Spanish specimens

Tablica 2. Srednja vrijednost gubitka mase (ML) određena za svaki proces i gustoća apsolutno suhog drva određena za svaki modificirani i nemodificirani referentni uzorak (standardne devijacije u zagradama) za čileanske i španjolske vrste drva eukalipta

\begin{tabular}{|c|c|c|c|}
\hline $\begin{array}{c}\text { Country of origin } \\
\text { Zemlja podrijetla }\end{array}$ & $\begin{array}{c}\text { Temperature, }{ }^{\circ} \mathbf{C} \\
\text { Temperatura },{ }^{\circ} \mathrm{C}\end{array}$ & $\mathbf{M L}, \%$ & $\begin{array}{c}\text { OD Density, } \mathbf{~ k g} / \mathbf{m}^{\mathbf{3}} \\
\text { Gustoća apsolutno suhog drva, } \mathrm{kg} / \mathrm{m}^{3}\end{array}$ \\
\hline \multirow{4}{*}{ Chile / Čile } & Reference & - & $617 \pm(16)$ \\
\cline { 2 - 4 } & 185 & $2.4 \pm(0.4)$ & $603 \pm(39)$ \\
\cline { 2 - 4 } & 200 & $6.1 \pm(1.0)$ & $592 \pm(23)$ \\
\cline { 2 - 4 } & 215 & $12.3 \pm(0.5)$ & $553 \pm(29)$ \\
\cline { 2 - 4 } & Reference & - & $574 \pm(26)$ \\
\cline { 2 - 4 } & 185 & $2.6 \pm(0.9)$ & $555 \pm(35)$ \\
\cline { 2 - 4 } Spain / Španjolska & 200 & $12.0 \pm(0.9)$ & $529 \pm(18)$ \\
\cline { 2 - 4 } & 215 & & $517 \pm(35)$ \\
\hline
\end{tabular}



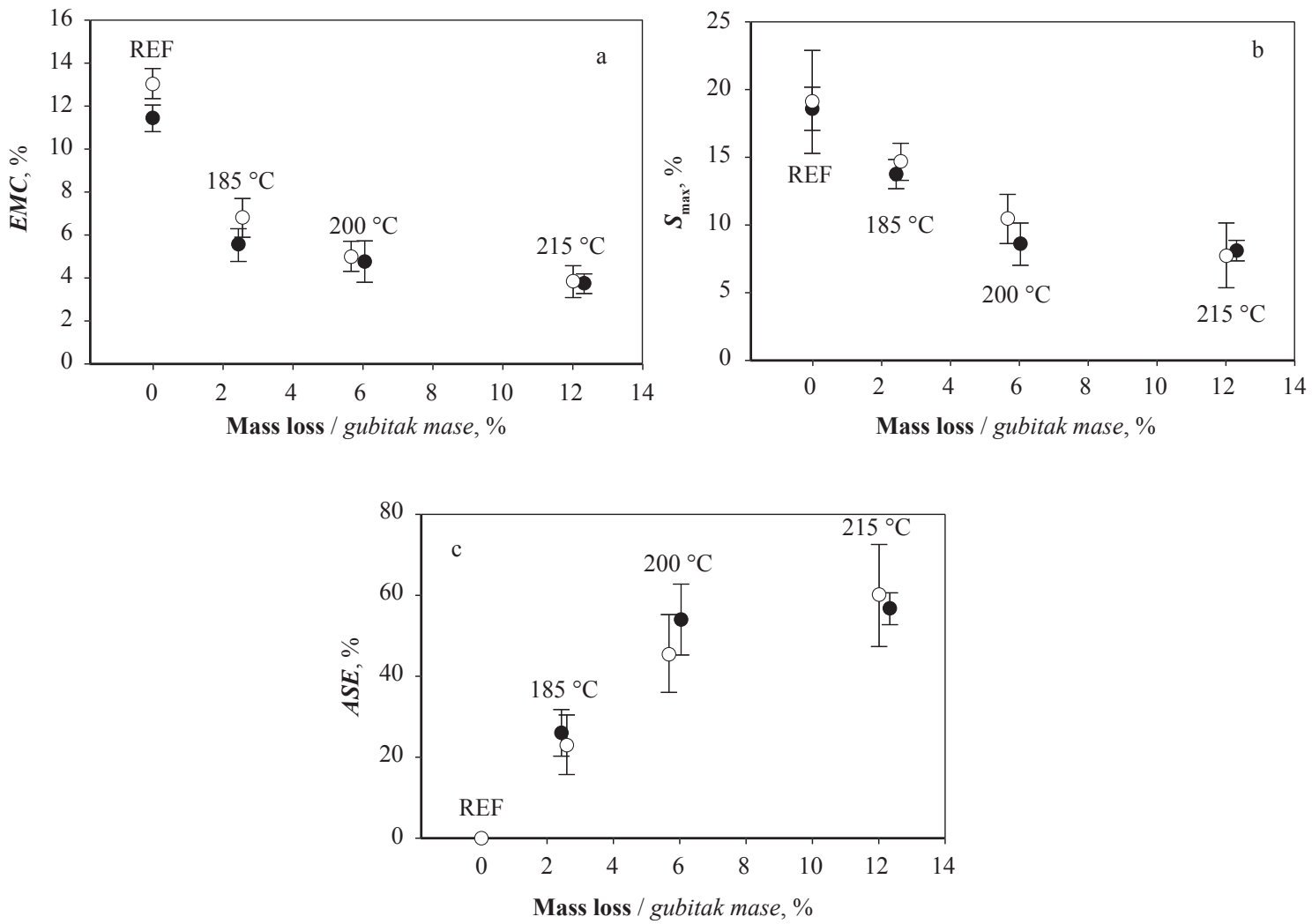

Figure $1 E M C$ at $20{ }^{\circ} \mathrm{C}$ and $65 \% \mathrm{RH}(\mathrm{a}), \mathrm{S}_{\max }$ (b) and $A S E$ (c) of $E$. nitens depending on the mass loss by thermal modification. Black circles: Chilean specimens. White circles: Spanish specimens. Standard deviations are indicated by error bars Slika 1. $E M C$ pri $20^{\circ} \mathrm{C}$ i $65 \% \mathrm{RH}\left(\right.$ a), $S_{\max }$ (b) i $A S E$ (c) drva E. nitens u ovisnosti o gubitku mase zbog toplinske modifikacije (crni krugovi - čileanski uzorci; bijeli krugovi - španjolski uzorci); standardne devijacije prikazane su kao stupci pogreške

dimensional stability in thermally modified wood was also shown for F. sylvatica and Fraxinus spp. (Živković et al., 2008). As for other eucalypt species, the $A S E$ of thermally modified E. globulus reported by Esteves et al. (2007b) was higher $\left(73-90 \%\right.$ at 190 to $\left.210^{\circ} \mathrm{C}\right)$.

\subsection{Changes in hardness, abrasion and screw} withdrawal by thermal modification

3.2. Promjene tvrdoće te otpornosti na habanje i izvlačenje vijaka zbog toplinske modifikacije

Static hardness (Brinell) of the Chilean material was higher than that of the Spanish material. A Pearson correlation test showed that only the decrease in density was statistically significantly correlated with the dynam- ic and static hardness in the Chilean specimens (Table 3), while the Spanish specimens showed an increase in hardness unrelated to their densities after thermal modification at $200^{\circ} \mathrm{C}$ (Figure 2). There was a slight decrease until $200{ }^{\circ} \mathrm{C}$, and then a clear difference between unmodified specimens and those modified at $215^{\circ} \mathrm{C}$, while the Spanish material showed a noticeable decrease after all modifications (Figure 2a). Dynamic hardness decreased with increasing treatment temperature in the Chilean specimens, while at $185^{\circ} \mathrm{C}$ and $200{ }^{\circ} \mathrm{C}$ similar results were obtained for the Spanish specimens (Figure $2 b)$. The static and dynamic hardness at all temperatures was lower compared to both WPC $\left(70 \mathrm{~N} / \mathrm{mm}^{2}\right)$ and tro-
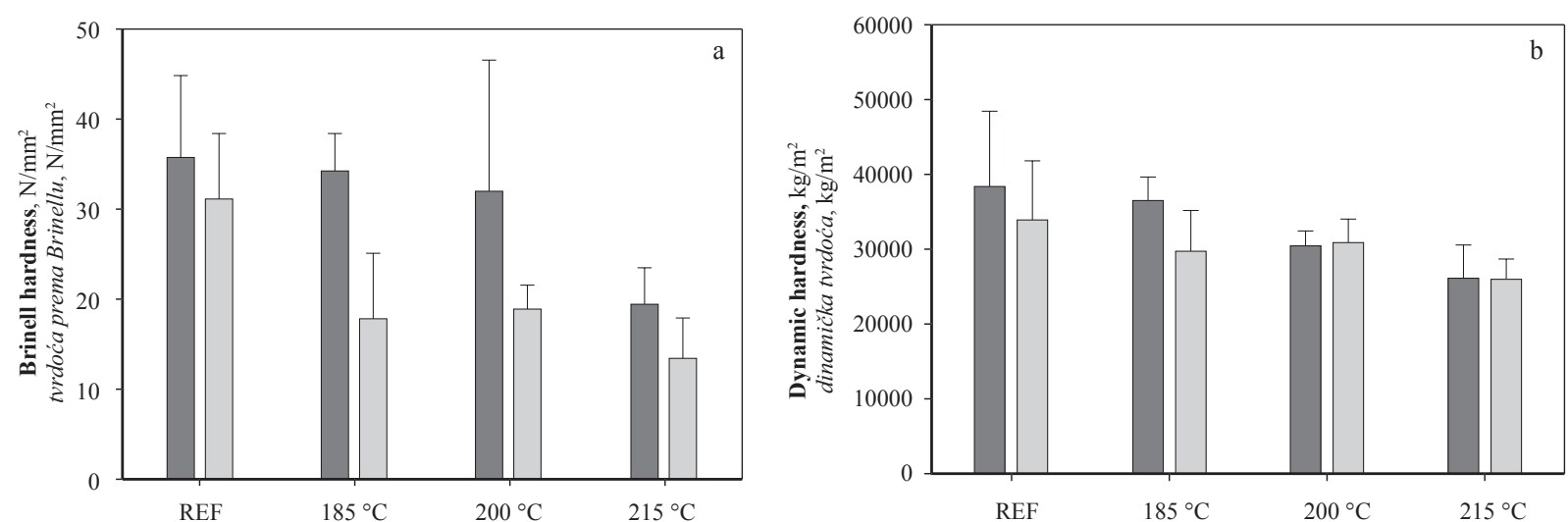

Figure 2 Brinell (a) and dynamic (b) hardness of E. nitens after each thermal modification process. Black column: Chilean specimens. Grey column: Spanish specimens

Slika 2. Tvrdoća prema Brinellu (a) i dinamička tvrdoća (b) drva E. nitens nakon svake toplinske modifikacije (crni stupci - čileanski uzorci; sivi stupci - španjolski uzorci) 


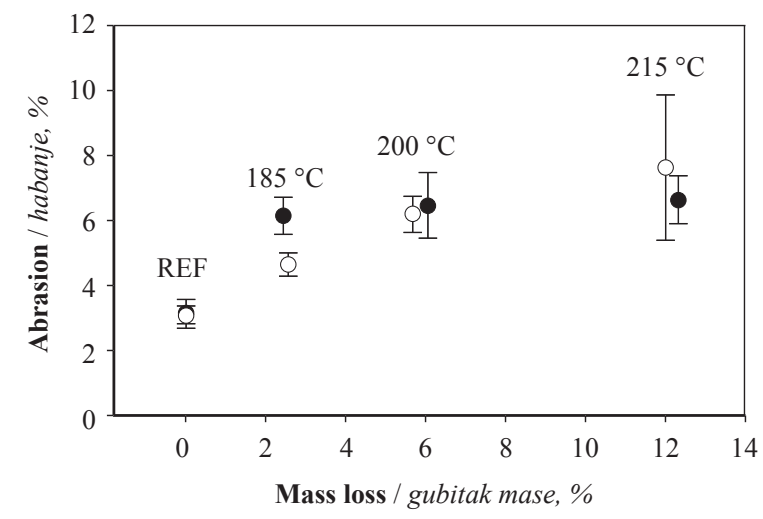

Figure 3 Abrasion of E. nitens after shaker tests depending on the mass loss by thermal modification. Black circles: Chilean specimens. White circles: Spanish specimens. Standard deviations are indicated by error bars

Slika 3. Otpornost na habanje drva E. nitens određena metodom Shaker u ovisnosti o gubitku mase zbog toplinske modifikacije (crni krugovi - čileanski uzorci; bijeli krugovi - španjolski uzorci); standardne devijacije prikazane su kao stupci pogreške

pical species, such as Bongossi (Lophira alata) and Balau (Shorea spp) (both $83 \mathrm{~N} / \mathrm{mm}^{2}$ ), but similar to Douglas fir $\left(35 \mathrm{~N} / \mathrm{mm}^{2}\right)$ and Beech $\left(39 \mathrm{~N} / \mathrm{mm}^{2}\right)$ (Brischke et al., 2014) at $200{ }^{\circ} \mathrm{C}$ for the Chilean specimens. The Brinell hardness was similar to thermally treated European beech and European ash $\left(35 \mathrm{~N} / \mathrm{mm}^{2}\right)$ treated between 180 and $200{ }^{\circ} \mathrm{C}$ in standard thermal modification under atmospheric conditions (Standfest and Zimmer, 2008), while the dynamic hardness was lower than that of European beech modified at $180{ }^{\circ} \mathrm{C}$ and with similar mass loss (Meyer et al., 2011).

The abrasion resistance of $E$. nitens decreased with increasing treatment intensity in all the specimens (Figure 3). Traces of abrasion on unmodified and thermally modified E. nitens at $215^{\circ} \mathrm{C}$ after the shaker test can be seen in Figures 4 and 5 for Chilean and Spanish specimens, respectively. The thermally modified specimen (Figure 4c, d and Figure 5c, d) had more severely rounded edges and a slight loss of material due to splintering. The reduced abrasion resistance is likely due to an increased brittleness of the material (Kubojima et al., 2000; Phuong et al., 2007), and the lower density of the material after thermal modification (Esteves and Pereira, 2009). Previous reports indicated that the decrease in abrasion resistance is correlated with the decrease in wood density (Brischke et al., 2014). This also occurred in both our Spanish and Chilean specimens, shown to be statistically significant in Table 3. Wentzel et al. (2019) showed that there was a decrease in the degree of polymerization of the cellulose in thermally modified E. nitens wood, which means that there was a change in the cellulose crystallinity. Estevez and Pereira (2009) suggest that changes in the cellulose crystallinity influence the mechanical
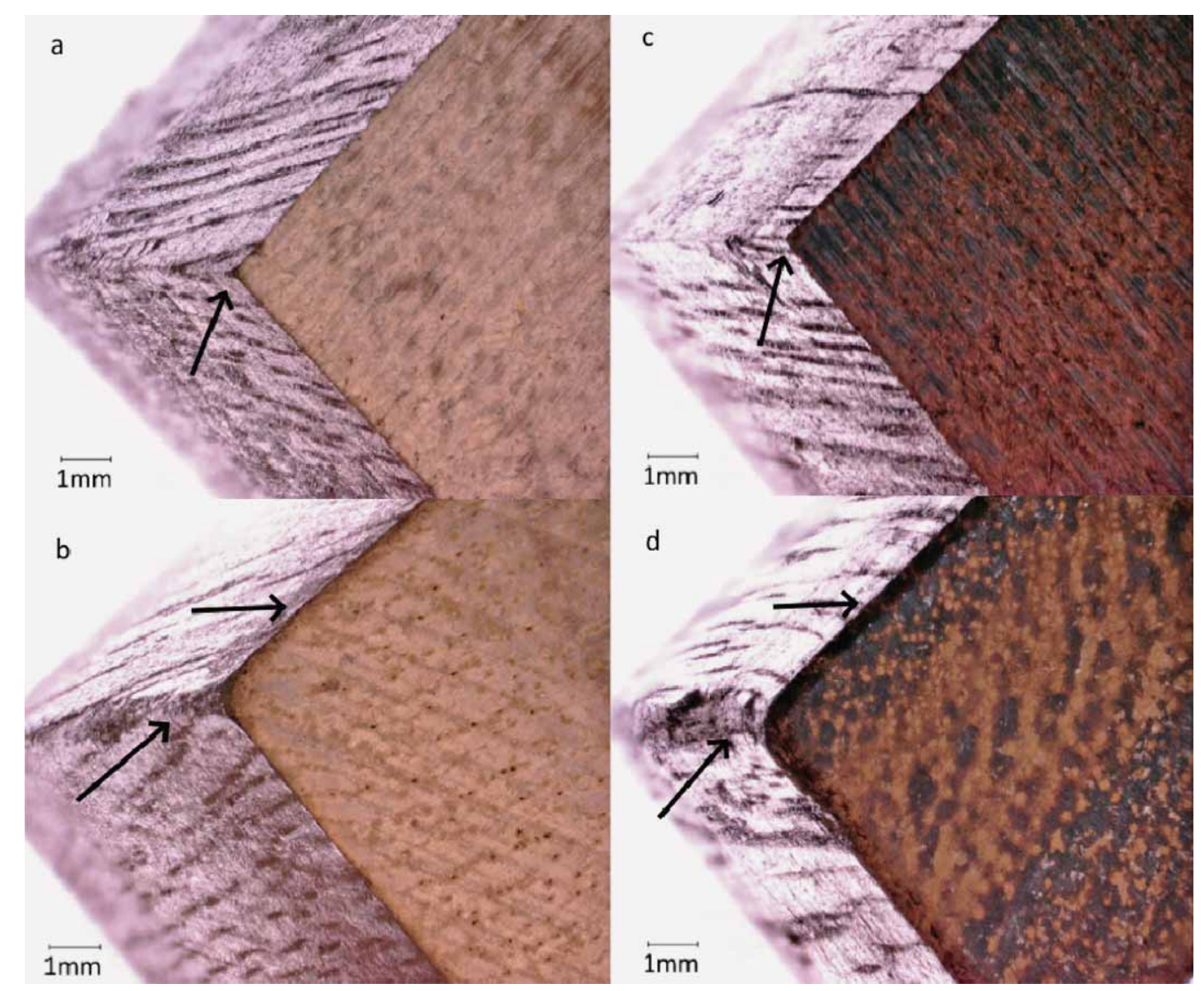

Figure 4 Cross section of $E$. nitens, unmodified and thermally modified at $215^{\circ} \mathrm{C}$ of the Chilean specimens before (a and c) and after ( $b$ and $d)$ the shaker abraser test. Arrows show the differences of wear between unmodified and modified specimens Slika 4. Poprečni presjek čileanskih nemodificiranih i na $215^{\circ} \mathrm{C}$ modificiranih uzoraka drva E. nitens prije (a i c) i nakon (b i d) ispitivanja otpornosti na habanje metodom Shaker; strelice pokazuju razlike u habanju između nemodificiranih i toplinski modificiranih uzoraka drva 

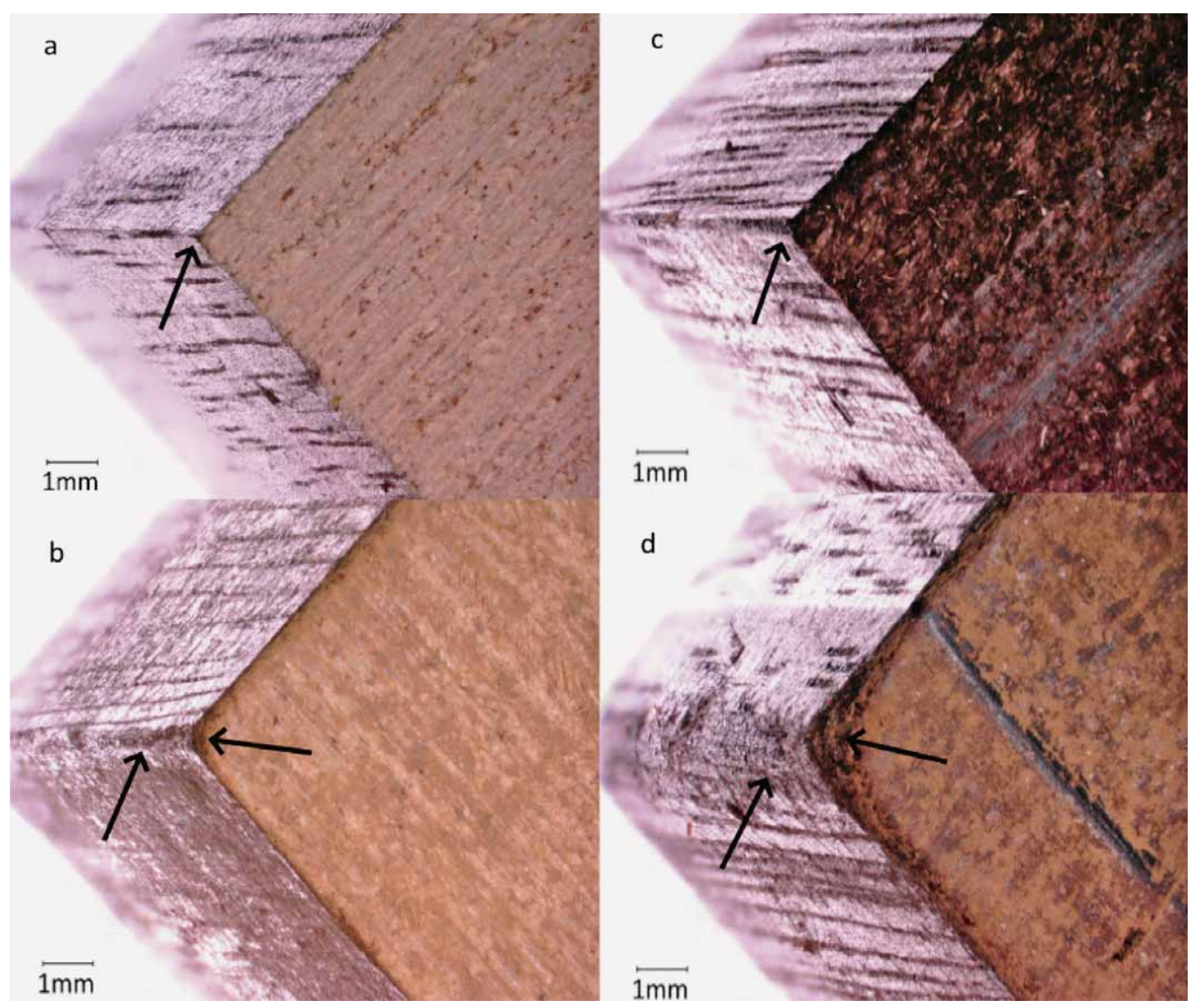

Figure 5 Cross section of E. nitens, unmodified and thermally modified at $215{ }^{\circ} \mathrm{C}$ of the Spanish specimens before (a and c) and after ( $b$ and $d)$ the shaker abraser test. Arrows show the differences of wear between unmodified and modified specimens Slika 5. Poprečni presjek španjolskih nemodificiranih i na $215^{\circ} \mathrm{C}$ modificiranih uzoraka drva $E$. nitens prije (a i c) i nakon (b i d) ispitivanja otpornosti na habanje metodom Shaker; strelice pokazuju razlike u habanju između nemodificiranih i toplinski modificiranih uzoraka drva

properties of thermally modified wood, which could also be an explanation of the reduction of abrasion resistance. Compared to other flooring materials, the unmodified E. nitens showed similar abrasion resistance as wood-polymer composites (WPC) and tropical species such as Balau (2.9 and $3 \%$ ), while E. nitens modified at $200^{\circ} \mathrm{C}$ and $215^{\circ} \mathrm{C}$ presented similar resistance to abrasion as Douglas fir and Norway spruce (Picea abies), and namely $6.2 \%$ (Brischke et al., 2014)

The abrasion expressed as $\Delta t$ increased with increasing modification temperature in the Spanish spe- cimens, while the Chilean specimens showed only small differences between modifications (Figure 6). The measurements were performed on finished decking (Figure 7), where the difference in $\Delta t$ can be seen between the modified specimens at $215{ }^{\circ} \mathrm{C}$ (Chile in Figure 7c and Spain in Figure 7d), more material being lost in the Spanish specimens.

The screw withdrawal resistance $(S W R)$ decreased with increasing treatment temperature, but did not differ between Spanish and Chilean E. nitens (Figure 8). Similar effects of thermal modification on

Table 3 Pearson correlation coefficients for mass loss and density in relation to $E M C, A S E$, shaker test, Taber Abraser test, Brinell hardness, dynamic hardness and SWR. Significant correlations $(\mathrm{p}<0.05)$ were marked with an asterisk $(*)$

Tablica 3. Pearsonov koeficijent korelacije za gubitak mase i gustoću u ovisnosti o $E M C$-u, $A S E$-u, metodi Shaker, metodi Taber abraser, tvrdoći prema Brinellu, dinamičkoj tvrdoći i $S W R$-u. Značajne korelacije označene su zvjezdicom (*).

\begin{tabular}{|c|c|c|c|c|}
\hline \multirow{3}{*}{$\begin{array}{c}\text { Proporties } \\
\text { Svojstva }\end{array}$} & \multicolumn{4}{|c|}{$\begin{array}{l}\text { Pearson correlation coefficient } \\
\text { Pearsonov koeficijent korelacije }\end{array}$} \\
\hline & \multicolumn{2}{|c|}{ Chile / Čile } & \multicolumn{2}{|c|}{ Spain / Španjolska } \\
\hline & $\begin{array}{c}\text { Mass loss } \\
\text { Gubitak mase }\end{array}$ & $\begin{array}{l}\text { Density } \\
\text { Gustoća }\end{array}$ & $\begin{array}{c}\text { Mass loss } \\
\text { Gubitak mase }\end{array}$ & $\begin{array}{l}\text { Density } \\
\text { Gustoća }\end{array}$ \\
\hline$E M C$ & $-0.996^{*}$ & $0.991 *$ & $-0.952 *$ & 0.994* \\
\hline$A S E$ & $0.797 *$ & $-0.913 *$ & $0.955^{*}$ & $-0.993 *$ \\
\hline Shaker Test / Metoda Shaker & $0.950^{*}$ & $-0.996^{*}$ & $0.977^{*}$ & $-0.979 *$ \\
\hline Taber Abraser Test / Metoda Taber abraser & $0.999^{*}$ & $-0.962 *$ & $0.943 *$ & $-0.996 *$ \\
\hline Brinell Hardness / Tvrdoća prema Brinellu & $-0.973 *$ & $0.896^{*}$ & $-0.873^{*}$ & 0.597 \\
\hline Dynamic Hardness / Dinamička tvrdoća & $-0.966^{*}$ & $0.999 *$ & $-0.856^{*}$ & 0.570 \\
\hline SWR & $-0.985^{*}$ & $0.998^{*}$ & $-0.805^{*}$ & 0.492 \\
\hline
\end{tabular}


Table 4 Average values of $E M C$, abrasion tests, hardness tests and screw withdrawal test of unmodified and modifies specimens. Significant differences with unmodified average values are marked by letter a. No significant differences are marked by letter $b$

Tablica 4. Srednja vrijednost $E M C$-a, otpornosti na habanje, tvrdoće i otpornosti na izvlačenje vijaka nemodificiranih i modificiranih uzoraka. Značajne razlike u odnosu prema srednjim vrijednostima nemodificiranih uzoraka označene su slovom a, dok su slučajevi bez značajne razlike označeni slovom b.

\begin{tabular}{|c|c|c|c|c|c|c|}
\hline Chile / Čile & $E M C, \%$ & $\begin{array}{c}\text { Shaker test } \\
\text { Metoda Shaker, \% }\end{array}$ & $\begin{array}{c}\text { Taber Abraser } \\
\text { test / Metoda } \\
\text { Taber abraser, \% }\end{array}$ & $\begin{array}{l}\text { Brinell hardness } \\
\text { Tvrdoća prema } \\
\text { Brinellu, N/mm² }\end{array}$ & $\begin{array}{c}\text { Dynamic hardness } \\
\text { Dinamička tvrdoća } \\
\mathrm{kg} / \mathrm{m} \cdot \mathrm{s}\end{array}$ & $\begin{array}{l}\boldsymbol{S W R}, \\
\mathrm{N} / \mathrm{mm}\end{array}$ \\
\hline $\begin{array}{c}\text { Unmodified } \\
\text { nemodificirani }\end{array}$ & $11.48^{\mathrm{a}}$ & $5.79^{\mathrm{a}}$ & $3.21^{\mathrm{a}}$ & $35.82^{\mathrm{a}}$ & $38341^{\mathrm{a}}$ & $48.68^{a}$ \\
\hline C185 & 5.55 & 7.41 & 6.15 & 34.24 & 36481 & 40.46 \\
\hline C200 & 4.75 & 7.91 & 6.46 & 32.08 & 30395 & 31.62 \\
\hline $\mathrm{C} 215$ & 3.76 & 8.96 & 6.64 & 19.51 & 26224 & 23.34 \\
\hline $\begin{array}{c}\text { Spain } \\
\text { Spanjolska }\end{array}$ & $E M C, \%$ & $\begin{array}{c}\text { Shaker test } \\
\text { Metoda Shaker, \% }\end{array}$ & $\begin{array}{c}\text { Taber Abraser } \\
\text { test / Metoda } \\
\text { Taber abraser, \% }\end{array}$ & $\begin{array}{l}\text { Brinell hardness } \\
\text { Tvrdoća prema } \\
\text { Brinellu, } \mathrm{N} / \mathrm{mm}^{2}\end{array}$ & \begin{tabular}{|c|} 
Dynamic hardness \\
Dinamička tvrdoća \\
$\mathrm{kg} / \mathrm{m} \cdot \mathrm{s}$
\end{tabular} & $\begin{array}{l}\boldsymbol{S W R}, \\
\mathrm{N} / \mathrm{mm}\end{array}$ \\
\hline $\begin{array}{c}\text { Unmodified } \\
\text { nemodificirani }\end{array}$ & $13.06^{a}$ & $3.41^{\mathrm{a}}$ & $3.06^{\mathrm{a}}$ & $31.19^{\mathrm{a}}$ & $33836^{b}$ & $47.36^{a}$ \\
\hline S185 & 6.81 & 4.93 & 4.67 & 17.88 & 29728 & 34.12 \\
\hline S200 & 5.00 & 8.41 & 6.20 & 18.91 & 30835 & 37.48 \\
\hline S215 & 3.81 & 10.51 & 7.63 & 13.52 & 25891 & 26.60 \\
\hline
\end{tabular}

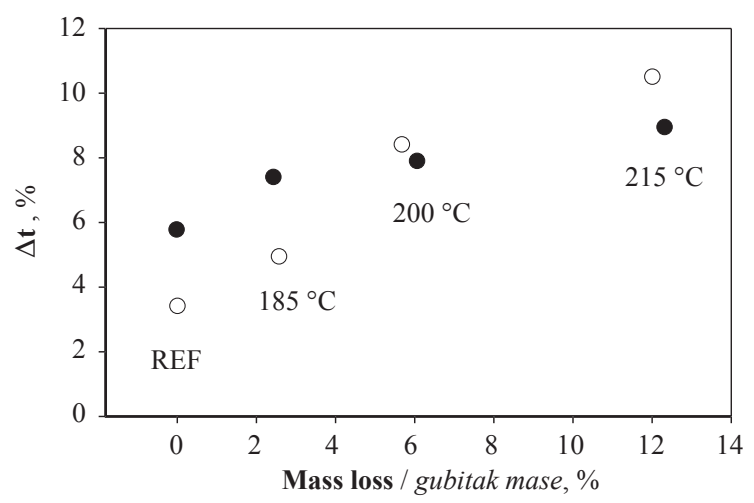

Figure 6 Abrasion of E. nitens after Taber Abraser tests depending on the mass loss by thermal modification. Black circles: Chilean specimens. White circles: Spanish specimens Slika 6. Otpotnost na habanje drva E. nitens određena metodom Taber abraser u ovisnosti o gubitku mase zbog toplinske modifikacije (crni krugovi - čileanski uzorci; bijeli krugovi - španjolski uzorci)

SWR were previously reported for birch (Poncsák et al., 2006) and wild cherry (Aytin et al., 2015).

\subsection{Statistical analysis}

\subsection{Statistička analiza}

The correlations presented in Table 3 show that mass loss was positively correlated with $A S E$ and negatively with the resistance to abrasion in the shaker and abraser test, EMC, SWR and dynamic and Brinell hardness. Most correlations were significant. Only density was not correlated with SWR and dynamic and Brinell hardness in the modified wood from Spain, due to a slight increase of the properties in the modification at $200^{\circ} \mathrm{C}$.

As for the ANOVA test, all properties presented significant differences between the unmodified and modified specimens, with the exception of the dynamic hardness of the modified samples from Spain, as can be seen in Table 4.

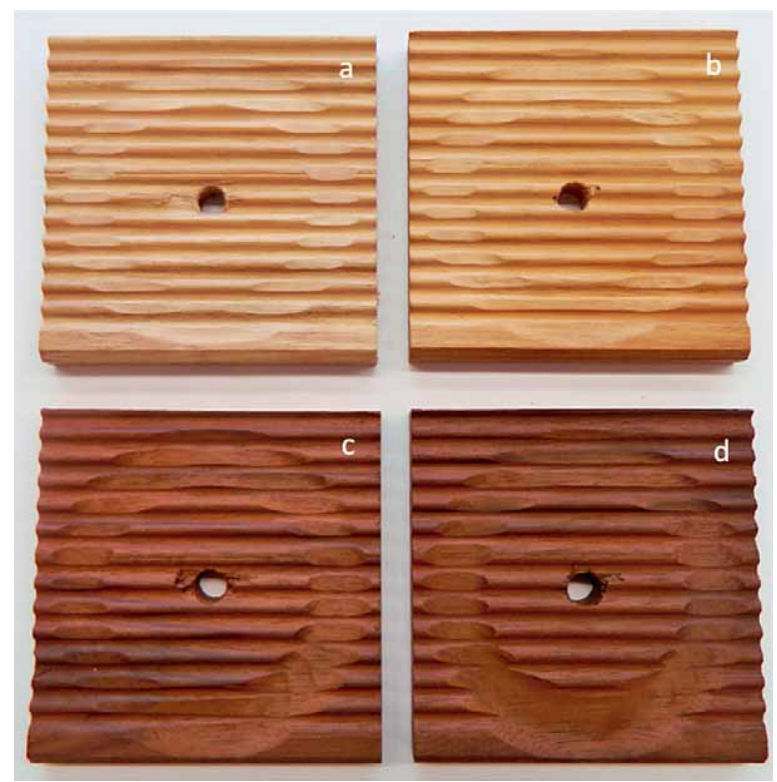

Figure 7 Finished decking specimens after the Taber Abraser test. E. nitens wood, unmodified and thermally modified at $215^{\circ} \mathrm{C}$ of the Chilean and Spanish specimens before ( $a$ and $b$ ) and after ( $c$ and d) the Taber Abraser test Slika 7. Uzorci vanjskih podnih obloga nakon ispitivanja otpornosti na habanje metodom Taber abraser; nemodificirani i na $215^{\circ} \mathrm{C}$ modificirani uzorci drva $E$. nitens iz Čilea i Španjolske prije (a i c) i nakon (b i d) ispitivanja otpornosti na habanje metodom Taber abraser

The results indicate that the characteristics of thermally treated $E$. nitens from our study, especially the modification at $200{ }^{\circ} \mathrm{C}$ for both countries, were similar to other species commonly used for decking, such as Douglas fir (Brischke et al., 2014), and other thermally modified species, like Larix decidua (Welzbacher et al., 2009), F. sylvatica and Fraxinus spp. (Živković et al., 2008), which means that the modified E. nitens wood could be a probable alternative for decking. 


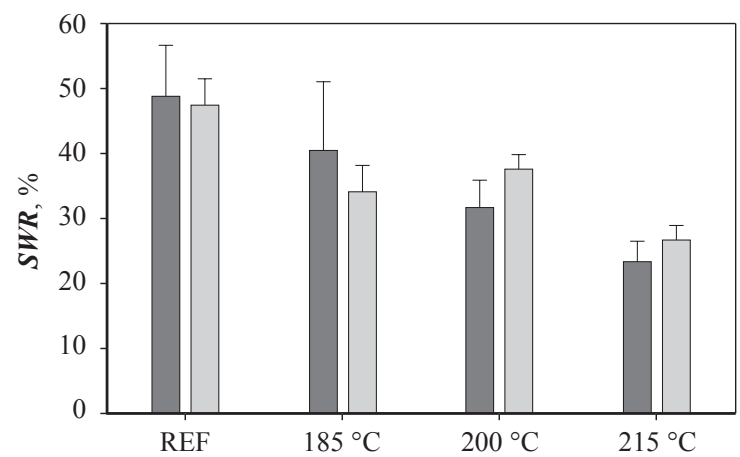

Figure 8 Screw withdrawal resistance of $E$. nitens depending on the mass loss by thermal modification. Black column: Chilean specimens. Grey column: Spanish specimens Slika 8. Otpornost na izvlačenje vijaka drva $E$. nitens u ovisnosti o gubitku mase zbog toplinske modifikacije (crni stupci - čileanski uzorci; sivi stupci - španjolski uzorci)

\section{CONCLUSIONS 4. ZAKLJUČAK}

Thermally modified E. nitens, from both Chile and Spain, showed very similar characteristics compared to each other. The properties obtained modifying at $200{ }^{\circ} \mathrm{C}$ were similar to other species commonly used for decking, showing high abrasion resistance and similar dynamic and static properties. This shows the potential of use of $E$. nitens as decking material, particularly modified at $200{ }^{\circ} \mathrm{C}$. To further develop the potential of this species as decking material, additional weathering and durability tests should be performed to determine the long-term use of this material.

\section{REFERENCES}

5. LITERATURA

1. Aytin, A.; Korkut, S.; As, N.; Ünsal, Ö.; Gündüz, G., 2015: Effect of heat treatment of wild cherry wood on abrasion resistance and withdrawal capacity of screws. Drvna industrija, 66 (4): 297-303. https://doi.org/10.5552/drind.2015.1440.

2. Brischke, C.; Iseler, N.; Meyer, L.; Sawyer, G., 2014: Testing the mechanical resistance of timber used for construction in the marine environment. International Wood Products Journal, 5: 39-49. https://dx.doi.org/10.1179/2042645313Y.0000000050.

3. Brischke, C.; Koch, S.; Rapp, A. O.; Welzbacher, C. R., 2005: Surface properties of thermally treated wood-wear abrasion and hardness. In: Proceedings of 2nd European Conference on Wood Modification, Hill, C. A. S.; Militz, H. (eds.). Göttingen, Germany, 6-7 October.

4. Calonego, F. W.; Severo, E. T. D.; Ballarin, A. W., 2012: Physical and mechanical properties of thermally modified wood from E. grandis. European Journal of Wood and Wood Products, 70: 453-460.

https://dx.doi.org/10.1007/s00107-011-0568-5.

5. Choong, E. T.; Achmadi, S. S., 2007: Effect of extractives on moisture sorption and shrinkage in tropical woods. Wood and Fiber Science, 23: 185-196.

6. de Cademartori, P. H. G.; Missio, A. L.; Mattos, B. D.; Gatto, D. A., 2015: Effect of thermal treatments on technological properties of wood from two Eucalyptus species. Anais da Academia Brasileira de Ciências, 87: 471-481. https://dx.doi.org/10.1590/0001-3765201520130121.
7. Dias, Z. D.; Alvarez, C. E., 2017: Mechanical properties: wood lumber versus plastic lumber and thermoplastic composites. Ambiente Construído, 17 (2): 201-219. http://dx.doi.org/10.1590/s1678-86212017000200153.

8. Esteves, B.; Domingos, I.; Pereira, H., 2007a: Improvement of technological quality of eucalypt wood by heat treatment in air at $170-200^{\circ} \mathrm{C}$. Forest Products Journal, 57: 47-52.

9. Esteves, B.; Marques, A. V.; Domingos, I.; Pereira, H., 2007b: Influence of steam heating on the properties of pine (Pinus pinaster) and eucalypt (Eucalyptus globulus) wood. Wood Science and Technology, 41: 193-207. https://dx.doi.org/10.1007/s00226-006-0099-0.

10. Esteves, B.; Pereira, H., 2009: Wood modification by heat treatment: a review. BioResources, 4: 370-404.

11. González-Prieto, O.; Touza Vázquez, M. C., 2009: Properties of thermally modified wood of Eucalyptus globulus from Spanish plantations. Document IRG/WP 0940469. International Research Group of Wood Protection, Stockholm.

12. Hill, C. A. S., 2006: Wood Modification: Chemical, Thermal and Other Processes. John Wiley \& Sons, Ltd., West Sussex, England.

13. Knapic, S.; Santos, J.; Santos, J.; Pereira, H., 2018: Natural durability assessment of thermo-modifi ed young wood of eucalyptus. Maderas Ciencia y tecnología, 20: 489-498 https://dx.doi.org/10.4067/S0718-221X2018005031801.

14. Kubojima, Y.; Okano, T.; Ohta, M., 2000: Bending strength and toughness of heat-treated wood. Journal of Wood Science, 46: 8-15. https://dx.doi.org/10.1007/bf00779547.

15. Mayes, D.; Oksanen, O., 2002: ThermoWood Handbook. Finnish Thermowood Association, Helsinki, Finland.

16. Metsä-Kortelainen, S.; Antikainen, T.; Viitaniemi, P., 2006: The water absorption of sapwood and heartwood of Scots pine and Norway spruce heat-treated at $170^{\circ} \mathrm{C}$, $190^{\circ} \mathrm{C}, 210^{\circ} \mathrm{C}$ and $230^{\circ} \mathrm{C}$. Holz Als Roh-und Werkstoff, 64: 192-197. https://dx.doi.org/10.1007/s00107-005-0063-y.

17. Meyer, L.; Brischke, C.; Welzbacher, C. R., 2011: Dynamic and static hardness of wood: method development and comparative studies. International Wood Products Journal, 2: 5-11. https://dx.doi.org/10.1179/2042645311Y.0000000005.

18. Militz, H.; Altgen, M., 2014: Processes and properties of thermally modified wood manufactured in Europe. In: Deterioration and protection of sustainable biomaterials, Schultz, T. P; Goodell, B.; Nicholas, D. D. (eds). ACS Symposium Series 1158. Oxford University Press, pp. 269-285.

19. Phuong, L. X.; Shida, S.; Saito, Y., 2007: Effects of heat treatment on brittleness of Styrax tonkinensis wood. Journal of Wood Science, 53: 181-186. https://dx.doi.org/10.1007/s10086-006-0841-0.

20. Poncsák, S.; Kocaefe, D.; Bouazara, M.; Pichette, A., 2006: Effect of high temperature treatment on the mechanical properties of birch (Betula papyrifera). Wood Science and Technology, 40: 647-663. https://dx.doi.org/10.1007/s00226-006-0082-9.

21. Stamm, A. J.; Hansen, L. A., 1937: Minimizing wood shrinkage and swelling effect of heating in various gases. Industrial and Engineering Chemistry, 29: 831-833. https://dx.doi.org/10.1021/ie50331a021.

22. Standfest, G.; Zimmer, B., 2008: The surface hardness of thermally treated woods. In: Poster presentation at $62^{\text {nd }}$ International Convention of the Forest Products Society, St. Louis, USA, 22-24 June 2008. 
... Wentzel, González-Prieto, Brischke, Militz: Physico-Mechanical Properties of Thermally...

23. Wang, X. H.; Fei, B. H.; Liu, J. L., 2014: Effect of vacuum heat treatment temperature on physical and mechanical properties of Eucalyptus pellita wood. Wood and Fiber Science, 46: 368-375.

24. Welzbacher, C. R.; Brischke, C.; Rapp, A. O.; Koch, S.; Hofer, S., 2009: Performance of modified timber (TMT) in outdoor application - durability, abrasion and optical appearance. Drvna industrija, 60 (2): 75-82.

25. Wentzel M., Fleckenstein M., Hofmann T., Militz H. (2019) Relation of chemical and mechanical properties of Eucalyptus nitens wood thermally modified in open and closed systems. Wood Material Science and Engineering 14 (3): 165-173. https://doi.org/10.1080/174802 72.2018 .1450783 . https://doi.org/10.1080/17480272.2018.1450783.

26. Zeller, F., 2018: Decking - Facade - Garden Timber: Product types and market share. In: Proceedings of the $10^{\text {th }}$ European TMT - Workshop, Dresden, Germany, 3-4 Mai 2018.

27. Živković, V.; Prša, P.; Turkulin, H.; Sinković, T.; JiroušRajković, V., 2008: Dimensional stability of heat treated wood floorings. Drvna industrija, 59 (2): 69-73.

28. ***AS 5604: 2005 Australian Standard: Timber - Natural durability ratings

29. ***DIN EN 320: 2011 Particleboards and fibreboards Determination of resistance to axial withdrawal of screws. European Committee for Standardization, Brussels.

30. ***DIN EN 438: 2005 High-pressure decorative laminates (HPL) - Sheets based on thermosetting resins (usu- ally called laminates), Part 2: Determination of properties. European Committee for Standardization, Brussels.

31. ***DIN EN 1534: 2011 Wood flooring - Determination of resistance to indentation - Test method. European Committee for Standardization, Brussels.

32. ***INFOR: 2015 Statistical bulletin $\mathrm{N}^{\circ} 154$ - Chilean statistical yearbook of forestry 2016. Instituto Forestal de Chile, Santiago de Chile.

33. ***ISO 13061-2: 2014 Physical and mechanical properties of wood - Test methods for small clear wood specimens, Part 2: Determination of density for physical and mechanical tests. International Organization for Standardization, Geneva.

34. ***2018: Xunta de Galicia $1^{\text {a }}$ Revisión del Plan Forestal de Galicia Santiago de Compostela, Spain.

\section{Corresponding address:}

MAXIMILIAN WENTZEL, Dr. rer. nat

University of Goettingen

Department of Wood Biology and Wood Products

Buesgenweg 4, 37077, Goettingen, GERMANY

ORCID: 0000-0002-5795-7589

e-mail: mwentze@gwdg.de 